\title{
Darwin's fishes: phylogeography of Galápagos Islands reef fishes
}

\author{
${ }^{1}$ Department of Ecology and \\ Evolutionary Biology, University \\ of California Santa Cruz, 100 \\ Shaffer Road, Santa Cruz, \\ California 95060.
}

${ }^{2}$ California Academy of Sciences, San Francisco, California 94118.

3 University of California Davis, Bodega Marine Laboratory, P.O. Box 247, Bodega Bay, California 94923.

${ }^{4}$ Ocean Science Foundation, 4051 Glenwood, Irvine, California 92604, and Guy Harvey Research Institute, Nova Southeastern University, 8000 North Ocean Drive, Dania Beach, Florida 33004.

${ }^{5}$ Department of Biology, Cabrillo College, Aptos, California 95060.

+ Present address: San Francisco State University, 1600 Holloway Ave., San Francisco, California 94132.

* Corresponding author email: <bernardi@biology.ucsc.edu>, telephone: +1 (831) 459 5124, fax: +1 (831) 4593383.

Date Submitted: 30 April, 2013. Date Accepted: 4 December, 2013. Available Online: 9 January, 2014.

\author{
Giacomo Bernardi ${ }^{{ }^{*}}$ \\ Marina L Ramon ${ }^{1}$ \\ Yvette Alva-Campbell ${ }^{1+}$ \\ John E McCosker ${ }^{2}$ \\ Giuseppe Bucciarelli ${ }^{1}$ \\ Lauren E Garske 3 \\ Benjamin C Victor ${ }^{4}$ \\ Nicole L Crane ${ }^{5}$
}

ABSTRACT.-Working in the Galápagos Islands and surrounding areas, we examined the relationship between population structure, a precursor to allopatric speciation, in species of reef fishes that exhibit different life history traits and three types of distributions in a nested setting: endemic (restricted to the Galápagos Islands), insular (Galápagos and neighboring islands), and Panamic (tropical eastern Pacific). We used a combination of population structure and coalescent approaches to assess the degree of genetic population structure in the three groups of fish species. In addition, we evaluated the level of inter-island genetic diversity in endemic species to determine if Galápagos fishes, like their terrestrial counterparts, could be used as a system to study allopatric speciation in the sea. We found that in general, there was no correlation between distribution ranges, life history traits, and population structure, except for Dialommus fuscus Gilbert, 1891, a Galápagos endemic that lives in the uppermost intertidal area, and as predicted, shows very strong population structure. We found the highest number of statistically significant population pairwise $F_{\mathrm{ST}}$ comparisons in endemic species. In addition, three out of four endemic species showed significant population pairwise $F_{\mathrm{ST}}[D$. fuscus, Lepidonectes corallicola (Kendall and Radcliffe, 1912), and Lythrypnus gilbert (Heller and Snodgrass, 1903)]. These results suggest that endemic Galápagos Islands reef fishes may be a promising group of species to study phylogeographic patterns of speciation.

"The (Galápagos) archipelago does not appear to offer a good laboratory for researching the impact of isolation, because the barren islands do not harbor many isolated fish pools." David Starr Jordan (in a letter to Robert Evans Snodgrass, 1898) 
Island populations have played a pivotal role in the elucidation of allopatric speciation, with the much-heralded Darwin finches as the most notable example (Darwin 1845, 1859, Lack 1947, Grant 2000). Islands, and island-like situations, such as volcanic freshwater lakes and mountain-tops, still play an essential role in helping develop our understanding of speciation processes and mechanisms (Duda and Rolán 2005, Thorpe 2005, Barluenga et al. 2006, Savolainen et al. 2006, Kahindo et al. 2007). The study of the origin of species is currently experiencing renewed interest with theoretical and empirical advances (Coyne and Orr 2004, Gravilets 2004, Barluenga et al. 2006, Savolainen et al. 2006, Price 2007, Crow et al. 2010), yet while much attention has been devoted to terrestrial and freshwater systems, comparatively little is known about speciation in marine environments (Palumbi 1994, Rocha and Bowen 2008, Miglietta et al. 2011, Bernardi 2013). This is particularly true for the potentially important island systems (Muss et al. 2001, Planes and Fauvelot 2002, Priest et al. 2012, van der Meer et al. 2012), likely due to the particulars of dispersal in marine organisms. Indeed, most marine species have a dispersive phase as gametes, eggs, or larvae, which lasts days to months in the pelagic environment (Leis 1991). There, oceanic currents transport propagules, sometimes over very long distances, that eventually recruit to their adult habitat where they may live a relatively sedentary life (Selkoe et al. 2010, Selkoe and Toonen 2011). Islands, which offer unique opportunities in terrestrial and freshwater systems (Baldwin and Sanderson 1998, Herder et al. 2006, Roderick et al. 2012), have traditionally not been seen as an interesting system for marine organisms due to their likely genetic connections to the mainland and to other islands via dispersal, as presumed by David Starr Jordan in his note to Snodgrass before the Hopkins-Stanford Galápagos Expedition of 1898-1899 (Larson 2001). However, while large-scale dispersal and its associated gene flow have been the general assumption in marine systems, a recent paradigm shift has occurred, with evidence of shorter dispersal and genetic structure resulting from unexpected highlevels of self-recruitment and local larval retention (Jones et al. 1999, 2005, Swearer et al. 1999, Berumen et al. 2012). In light of the potential for restricted dispersal in marine organisms, the role of islands may regain a place of importance in the study of marine population structure and speciation.

One powerful approach to assess the combined role of biotic and abiotic factors on population structure has been to use multiple species in a phylogeographic framework (Avise 1992, 2000). For fishes, the use of species with different life history traits, such as differences in pelagic larval duration and spawning modes, has shed light on the relationships between dispersal potential, population structure, and ultimately speciation (Waples 1987, Doherty et al. 1995, Shulman and Bermingham 1995, Riginos and Victor 2001, Klanten et al. 2004, Winters et al. 2010).

In the present study, we worked in the Galápagos Islands and surrounding areas, where we examined the relationship between population structure, a potential precursor to allopatric speciation, in species of reef fishes that exhibit different distributions and different life history strategies. Geographic ranges encompassed three distributions: endemic, for species found only in the Galápagos Islands; insular, for species found in the Galápagos Islands and adjacent islands such as Cocos Island; and Panamic, which is a biogeographic region that extends from $25^{\circ} \mathrm{N}$ (southern Baja California, Mexico) to $6^{\circ} \mathrm{N}$ (northern Peru) (Briggs and Bowen 2012). The Galápagos are oceanic islands that lie within the Panamic biogeographic province, and are located approximately $1000 \mathrm{~km}$ west of the coast of Ecuador (Jackson 1985, 


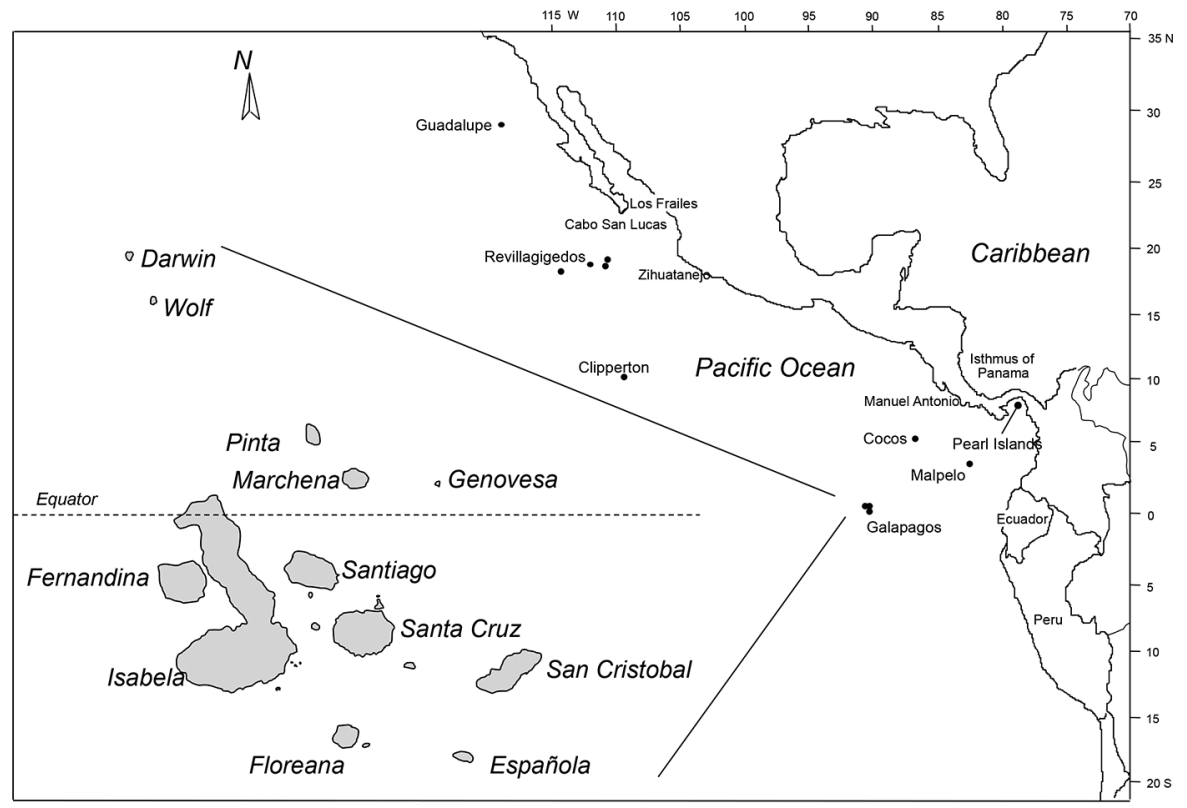

Figure 1. Partial map of the tropical eastern Pacific with an emphasis with the sampling sites of this study. The region of the Galápagos Islands was enlarged for better representation.

Larson 2001) (Fig. 1). The archipelago supports a diverse marine fish fauna primarily of Panamic affinity (Grove and Lavenberg 1997, McCosker and Rosenblatt 2010), with approximately 75 species being endemic (McCosker and Rosenblatt 1984, 2010, Allen and Robertson 1994, Grove and Lavenberg 1997, Humann and DeLoach 2003). In addition, 20 species are semiendemic or "insular," with distributions mainly centered on the Galápagos Islands, but with adjacent populations found on the islands of Cocos (Costa Rica), and Malpelo (Colombia) (McCosker and Rosenblatt 1975, 1984, 2010, Garrison 2005) (Fig. 1). Species also differed in life history traits. We tried to limit the variability of traits by selecting species that were mainly substrate spawners and with pelagic larval duration with a relatively narrow range, between a few days to a few weeks (Table 1). Finally, for intertidal species, we selected species that were found in the low, middle, and high intertidal areas.

Based on these characteristics, we used a nested sampling design with species distributions that ranged from endemic, to insular, to Panamic, and with different life history trait characteristics (Table 1). We selected two species that are widespread in the Panamic region, the king angelfish, Holacanthus passer Valenciennes, 1846, and the Panamic sergeant major, Abudefduf troschelii (Gill, 1862); two species with insular distributions, the Galápagos ringtail damselfish, Stegastes beebei (Nichols, 1924), and the yellowtail damselfish, Stegastes arcifrons (Heller and Snodgrass, 1903); and finally four reef fish species that are Galápagos endemics, two intertidal species, the Galápagos foureye blenny, Dialommus fuscus Gilbert, 1891, which lives in the higher intertidal (Nieder 2001), and the spotbelly blenny, Malacoctenus zonogaster Heller and Snodgrass, 1903, which lives in the lower intertidal, and two subtidal species, the Galápagos bluebanded goby, Lythrypnus gilberti (Heller and Snodgrass, 1903), 
Table 1. Life history traits of species in the present study. Egg type is either benthic for substrate spawners or pelagic for broadcast spawners. Pelagic larval duration (PLD) is given in days with its associated reference. Asterisk indicates that pelagic larval duration is unknown for Dialommus fuscus and Holacanthus passer. Values given are for Malacoctenus and Pygoplites, which are the closest genera to Dialommus and Holacanthus, respectively (Stepien et al. 1993, Alva-Campbell et al. 2010).

\begin{tabular}{lccl}
\hline Species & Egg type & PLD & Reference \\
\hline Endemic & & & \\
$\quad$ Dialommus fuscus & benthic & $24.0-25.0^{*}$ & Riginos and Victor 2001 \\
$\quad$ Lepidonectes corallicola & benthic & 30.0 & Present study \\
$\quad$ Lythrypnus gilberti & benthic & 50.0 & Present study \\
$\quad$ Malacoctenus zonogaster & benthic & 25.0 & Present study \\
Insular & & & \\
$\quad$ Stegastes arcifrons & benthic & 25.3 & Wellington and Victor 1989 \\
$\quad$ Stegastes beebei & benthic & 31.2 & Wellington and Victor 1989 \\
Panamic & & & \\
$\quad$ Abudefduf troschelii & benthic & 18.1 & Wellington and Victor 1989 \\
Holacanthus passer & pelagic & $23.0-26.0^{*}$ & Thresher and Brothers 1985 \\
\hline
\end{tabular}

and the Galápagos triplefin blenny, Lepidonectes corallicola (Kendall and Radcliffe, 1912). All species are substrate spawners except for $H$. passer, which broadcasts its eggs. Pelagic larval duration varied between an average of 18.1 (A. troschelii) to 50 (L. gilberti) d, with all other species being comprised between 23 and $32 \mathrm{~d}$ (Table 1).

We gathered samples from locales that covered the geographic distribution of the species. For widespread species, we obtained samples from Mexico, Costa Rica, Panama, and the Galápagos, for insular species, we obtained samples from Cocos Island and the Galápagos, and finally for endemic Galápagos species, we obtained samples from several islands within the archipelago (Table 2).

One goal of our study was to determine if insularity is related to population structure and, since we used a comparative approach, alternative hypotheses could be tested. In general, endemic species of marine organisms are believed to be poor dispersers, very rarely being able to reach oceanic islands, later diversifying locally without further contact with the mainland, potentially resulting in characteristic genetic signatures. Namely, we postulated that endemic species were likely to exhibit small population sizes and very limited dispersal (preventing connectivity with the mainland), while widespread species would have the largest populations and dispersal potential. Thus, at the genetic level, we predicted that genetic diversity would be low in endemic species, intermediate in insular species, and high in Panamic species. Gene flow levels would also be different. Overall, gene flow between populations is predicted to be low, medium, and high in endemic, insular, and Panamic species, respectively. In addition, egg type was predicted to play a role, with species with benthic eggs exhibiting less gene flow than species with pelagic eggs, as shown in previous studies (Riginos et al. 2011). Similarly, species with long pelagic larval durations are presumed to exhibit higher gene flow levels than species with shorter pelagic larval durations (Treml et al. 2012). Finally, intertidal species that live in the high intertidal are likely to exhibit lower levels of gene flow than species that live in the lower intertidal. Indeed, species restricted to the high shore may show greater levels of population structuring, as the potential for dispersal may be more limited compared 
Table 2. Sampling locations and numbers of eight species of marine fishes: Dialommus fuscus, DFU; Lepidonectes corallicola, LCO; Lythrypnus gilberti, LGI; Malacoctenus zonogaster, MZO; Stegastes arcifrons, SAR; Stegastes beebei, SBE; Abudefduf troschelii, ATR; Holacanthus passer, HPA.

\begin{tabular}{|c|c|c|c|c|c|c|c|c|}
\hline \multirow[b]{2}{*}{ Location } & \multicolumn{4}{|c|}{ Endemic } & \multicolumn{2}{|c|}{ Insular } & \multicolumn{2}{|c|}{ Panamic } \\
\hline & DFU & LCO & LGI & MZO & SAR & SBE & ATR & HPA \\
\hline \multicolumn{9}{|l|}{ Mexico } \\
\hline Los Frailes & & & & & & & 15 & 15 \\
\hline Zihuatanejo & & & & & & & 8 & 7 \\
\hline \multicolumn{9}{|l|}{ Costa Rica } \\
\hline Manuel Antonio & & & & & & & 15 & 3 \\
\hline Cocos Island & & & & & 2 & 1 & & \\
\hline \multicolumn{9}{|l|}{ Panama } \\
\hline Isla Contadora (Pearl Islands) & & & & & & & 15 & 12 \\
\hline \multicolumn{9}{|l|}{ Galápagos Islands } \\
\hline Wolf & & & & & & 6 & & \\
\hline Marchena & & & & & & 2 & & \\
\hline Santa Cruz & 17 & 7 & 9 & 10 & 7 & & & 1 \\
\hline Isabela & 1 & 11 & 4 & 8 & 6 & 6 & 14 & \\
\hline Fernandina & & & & & & 7 & & \\
\hline Española & 2 & 9 & 4 & 6 & 6 & 7 & & 1 \\
\hline Floreana & 15 & 4 & 13 & 10 & 9 & 4 & & 1 \\
\hline San Cristóbal & 13 & 9 & 6 & 10 & 9 & 4 & & \\
\hline
\end{tabular}

to organisms that inhabit the mid to low shore (all other things being equal). This is a function of time spent submerged during tidal cycles, and thus time available for movement, spawning, and the subsequent broadcasting of propagules, as was shown empirically in several studies on marine organisms (Huang and Bernardi 2001, Kelly and Palumbi 2010, von der Heyden et al. 2013).

To test these hypotheses, we used DNA sequences of the hypervariable $5^{\prime}$ end of the mitochondrial control region. Using a combination of population structure, coalescent approaches, and a new metric to compare haplotype networks (called Haplotype Network diversity, HNd), we assessed the degree of genetic diversity, complexity, and population structure in the three groups of fish species. In addition, we evaluated the level of inter-island genetic diversity in endemic species to determine if Galápagos fishes, like their terrestrial counterparts, could be used as a model for allopatric speciation.

\section{Materials And Methods}

\section{Selection of Species and Sampling}

As mentioned above, we have selected species that display three types of distributions, endemic to the Galápagos Islands, insular, and Panamic. Two of those species, D. fuscus and S. beebei, warrant further discussion regarding our choice of distribution patterns. Dialommus is a blennioid genus of the family Labrisomidae that includes two species, D. macrocephalus and D. fuscus (McCosker et al. 2003). While D. macrocephalus (formerly described as Mnierpes macrocephalus) is distributed along the mainland from Mexico to Colombia (Allen and Robertson 1994), D. fuscus is known from the Galápagos Islands and is said to also be from Cocos Island and 
Costa Rica (Grove and Lavenberg 1997). Although it is a common intertidal species, none have been collected or verified by observation at Cocos Island (G Garrison, USGS, Florida, in litt.). The Costa Rican record mentioned by Grove and Lavenberg (1997) citing earlier work (Herald and Herald 1973) is in fact an observation from a 1932 expedition (Clark 1936), and is certainly a misidentification for Dialommus macrocephalus (Günther, 1861) (Bussing and Lopez 2005). So here we consider a most likely scenario where D. fuscus is a Galápagos endemic. Stegastes beebei (known from the Pearl Islands, Panama, and Malpelo, Cocos, and the Galápagos islands) is considered by some (Allen and Woods 1980, Allen 1991, Allen and Robertson 1994) to be a subspecies of $S$. leucorus, which is known from the lower Gulf of California, the Revillagigedo, and Guadalupe islands. We consider them to be separate species. We did, however, include samples of S. leucorus from Guadalupe Island, Mexico, to substantiate our choice.

Intertidal species D. fuscus and M. zonogaster were collected with hand nets in tidepools. The remaining subtidal species were collected with hand nets and spear while free or scuba diving. Sampling locations and numbers are described in Table 2.

\section{Estimates of Pelagic Larval Duration}

We estimated the duration of the pelagic larval phase for three Galápagos endemics, L. corallicola, L. gilberti, and M. zonogaster counting daily rings and visualizing settlement marks following published protocols (Wellington and Victor 1989) (Table 1). Unfortunately no appropriate sample of $D$. fuscus and $H$. passer could be obtained for estimating the pelagic larval duration of these species. In these cases, pelagic larval duration estimates for their closest relatives, Malacoctenus and Pygoplites, respectively, were used (Stepien et al. 1993, Alva-Campbell et al. 2010).

\section{PCR And Sequence Analysis}

Amplification of the highly variable $5^{\prime}$ end of the mitochondrial control region was accomplished with the universal CR-A (TTC CAC CTC TAA CTC CCA AAG CTA G) and CR-E (CCT GAA GTA GGA ACC AGA TG) primers (Lee et al. 1995), except for the two species of Stegastes, where a primer in the position of CR-E was specifically designed for these species: STDLOOP.H1 CTG GAY AGA YRG CAC GGC ATG G. Data on size of the amplified fragment for each species and polymorphic sites are given in Table 2. Each $13 \mu \mathrm{l}$ PCR reaction contained 10-100 ng of DNA, $10 \mathrm{mM}$ Tris $\mathrm{HCl}$ (pH 8.3), $50 \mathrm{mM} \mathrm{KCl}, 1.5 \mathrm{mM} \mathrm{MgCl}$, $150 \mathrm{mM}$ of each dNTP, 2.5 units of Taq DNA polymerase (Perkin-Elmer, Norwalk, CT), and $0.3 \mathrm{mM}$ of each primer. PCR amplification was conducted using a profile of $45 \mathrm{~s}$ at $94{ }^{\circ} \mathrm{C}$ for the denaturation step, an annealing step of $45 \mathrm{~s}$ at temperatures ranging between 46 to $54{ }^{\circ} \mathrm{C}$ depending on the species, and an extension step of $1 \mathrm{~min}$ at $72{ }^{\circ} \mathrm{C}$, for 35 cycles. Reactions without genomic DNA were included in every amplification series to screen for possible foreign DNA contamination. Once purification following the manufacturer's protocol (Applied Biosystems, Foster City, CA), sequencing was performed using the CR-A primer after having checked a subset of sequences obtained by sequencing in both directions.

\section{Sequence Diversity and Variability}

Sequences were trimmed and aligned using the MAFFT routine (Katoh et al. 2002) implemented in Geneious 5.0 (Biomatters). Mitochondrial DNA variability was estimated by computing haplotype diversity, $\mathrm{Hd}$, and nucleotide diversity $\pi$ (Nei 
1987) using DNAsp (Librado and Rozas 2009). We used jModeltest 0.1.1 (Posada and Crandall 1998) to determine the substitution model that best fit the data based on the corrected Aikake Information Criterion.

\section{HAPLOTYPE NeTWORKS}

Relationships between intraspecific haplotypes within each species were assessed using a Minimum Spanning Network (MSN) or Haplotype Network (Excoffier and Smouse 1994). Haplotype networks based on control region sequences were generated in $\mathrm{R}$ using HaploNet in the APE package (Paradis et al. 2004) combined with pie diagrams of haplotype frequencies obtained with $A P E$ and Arlequin (Excoffier and Lischer 2010).

Haplotype Network Diversity.-To easily compare haplotype networks, we devised a single metric that captured in a simple form the complexity of a given haplotype network. This method combines a metric for haplotype diversity (Nei 1987) with a metric of node diversity. This latter metric was obtained similarly to haplotype diversity by computing the frequency of each type of node (unique haplotype), ranked by numbers of branches stemming from it. A terminal node being ranked 1, an intermediate node linking two nodes ranked 2, etc... thus each haplotype network was characterized by:

$$
H N d=\left(1-\Sigma f h i^{2}\right) \cdot n / n-1 \times\left(1-\sum f n i^{2}\right) \cdot n u / n u-1
$$

where $H N d$ is Haplotype Network diversity and the two main terms are haplotype diversity $(H d)$ multiplied by node diversity $(N d)$. Where $f h i$ is the frequency of each unique haplotype, $f n i$ is the frequency of each unique node, $n$ is the number of haplotypes, and $n u$ is the number of nodes (unique haplotypes). This new metric varies between 0 and 1 and allows for simple comparison between different haplotype networks.

\section{Population Structure}

Population structure was evaluated using an analysis of molecular variance (AMOVA) (Excoffier et al. 1992), as well as classical fixation indexes ( $F_{\mathrm{ST}}$ values) implemented in Arlequin (Excoffier and Lischer 2010) based on pairwise genetic distances using unweighted transitions and transversions. Deviations from values expected under the null hypothesis of genetic homogeneity were tested using a nonparametric permutation approach using 1000 replicates (Excoffier et al. 1992).

For AMOVA analyses, we tested the genetic structure (1) within populations, (2) between populations within a region, and (3) between regions. We defined regions as populations belonging to a particular group of islands since different currents, salinity, and temperature regimes occur in these regions. All populations with fewer than three sampled individuals were removed from the analyses.

\section{Historical Demography}

Historical demography (population fluctuations based on coalescent models) was evaluated using the program LAMARC (Kuhner 2006). Population parameters $\Theta=$ $2 N \mu$, where $\mu$ is the mutation rate for mtDNA and $g$ (the exponential growth parameter in units of $\mu$ ) were estimated, the parameter $\Theta$ being estimated with population growth (parameters are estimated jointly) or with growth kept constant $(g=0)$. Both 
estimates were obtained by running five replicates, which generated a mean value and its associated standard deviation. Analysis of each data set was done with 10 short Monte Carlo chains of 4000 steps each and five long chains of 20,000 steps, with a sampling increment of 20 .

Coalescence times were estimated by assuming that coalescence was reached when the population size was reduced to $1 \%$ of its present-day value (Wares and Cunningham 2001). To estimate coalescence time, we used a mutation rate $(\mu)$ as $\mu$ = substitutions per site per generation obtained for a pairs of Trans-Isthmian geminate reef fishes of the genus Chromis (Domingues et al. 2005, 2006), thus providing a window of mutation rates $\left(8.24 \times 10^{-8}\right.$ to $\left.9.30 \times 10^{-8}\right)$.

\section{REsUlts}

\section{Sequence Characteristics}

Samples obtained for the eight species investigated here are described in Table 2, sampling locations are shown on Figure 1. All sequences and their collection sites were deposited in GenBank with accession numbers KC797689-KC798053. Mitochondrial control regions were obtained for a total of 358 individuals: sequence sizes and number of polymorphic sites are given in Table 3 . The number of haplotypes per species varied between 16 and 63 and in general, haplotype diversity was high, varying between 0.785 for L. gilberti, and 0.998 for M. zonogaster (Table 3).

\section{HAPLOTYPE NeTWORKS}

Reconstructed haplotype networks are shown on Figure 2. Samples of S. leucorus from Guadalupe Island, Mexico, grouped together and were separated from insular samples of $S$. beebei by 27 unique substitutions, thus being consistent with the idea that these entities represent two different species and that S. beebei is correctly classified here as an insular species.

For the present study, we needed to compare the complexity of haplotype networks among different species. We established a new metric, Haplotype network diversity (HNd) that can describe the diversity of the topology of the network with a single number that varies between 0 and 1 . The $\mathrm{HNd}$ metric seems to properly capture the complexity of the networks. HNd values varied between 0.367 for S. beebei (excluding the samples collected at Guadalupe Island, which are assigned to S. leucorus as noted above), and 0.922 for $A$. troschelii. Indeed these two networks appeared least and most complex, respectively. Conversely, $\mathrm{HNd}$ values for $M$. zonogaster (0.898) and $A$. troschelii $(0.922)$ were similar, and these two networks were similarly complex. On average, HNd was 0.754 for endemic species, 0.563 for insular species, and 0.843 for Panamic species.

Within the endemic species, there was no obvious trend in HNd values between intertidal and subtidal species, the two most complex networks were found in one subtidal and one intertidal species, L. corallicola and M. zonogaster, respectively, and the two least complex networks were also found in one subtidal species, L. gilberti, and interestingly in the higher intertidal species $D$. fuscus. For insular species, two species in the same genus, Stegastes, displayed haplotype networks with very different complexities (HNd 0.367 and 0.766). Finally, the widespread Panamic species showed complex networks (HNd 0.764 and 0.922). 


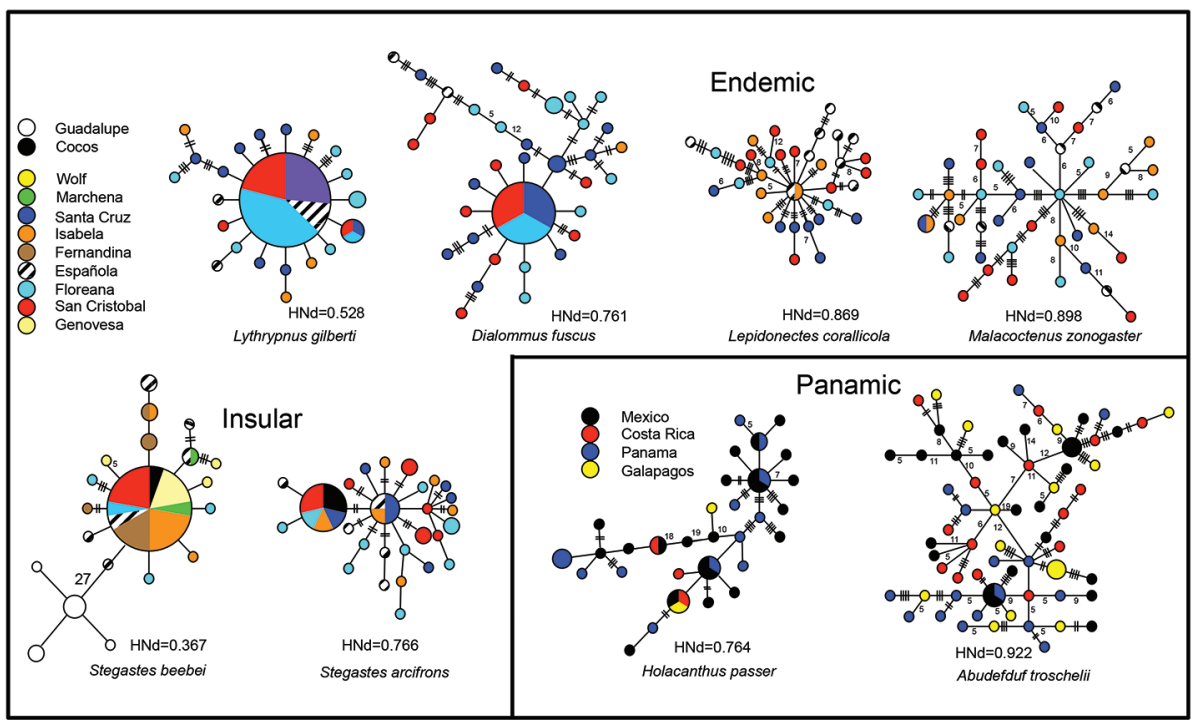

Figure 2. Haplotype network for the control region for endemic, insular, and Panamic species of fish. The size of the circles is proportional to the frequency of each haplotype. Each line represents one mutational step, unless otherwise shown. A value for Haplotype network diversity $(\mathrm{HNd})$ is shown next to each network. Each sampling site is labeled with a unique color that is shown on the left legend for endemic and insular fishes, and within the box for Panamic species. For the network associated with Stegastes beebei, the white circles correspond to the closely related species Stegastes leucorus.

\section{Population Structure}

An analysis of molecular variance (AMOVA) was performed on our focal species, by attempting to group locations within the Galápagos Archipelago for the endemic and insular species (groups included northern versus southern islands, and eastern versus western islands) and by grouping Galápagos samples against other Panamic locales for the Panamic species. In no cases did we find statistically significant groupings ( $F_{\mathrm{CT}}$ values not significant, not shown).

Population structure at finer scale was evaluated using $F_{\mathrm{ST}}$ values and the number of significant pairwise comparisons between populations (Table 3). We found that $F_{\mathrm{ST}}$ values varied between 0 and the highest value of 0.338 for the higher intertidal endemic species, $D$. fuscus (Table 3). The number of species with significant pairwise $F_{\text {ST }}$ values was high among the endemics (three out of four species). That number was not correlated with the number of locales under consideration. Indeed, the two species with the largest number of locales, S. beebei and H. passer (nine locales each), both showed no significant pairwise comparisons. In contrast, $D$. fuscus, which was collected at the smallest number of locales (five populations) had three pairwise comparisons that were statistically significant (Table 3).

\section{Life History Traits and Ecological Characteristics}

We did not find a noticeable difference between species with benthic vs pelagic eggs, or with high vs low pelagic larval durations. This has been seen before in other systems and has been assigned, among other things, to the strong influence of larval behavior or the ecology of the adults that may override other traits such as pelagic larval durations (Selkoe and Toonen 2011, Luiz et al. 2013). As mentioned above, we 
Table 3. Genetic characteristics of fish species investigated in this study based on mitochondrial hypervariable region (control region). The entire data set was used to generate these data. Columns represent sample numbers $(n)$, length of DNA sequences (Seq.), number of polymorphic sites (pol.), number of haplotypes $(\mathrm{nH})$, nucleotide diversity $(\pi)$, haplotype diversity $(\mathrm{Hd})$, node diversity (Nd), Haplotype Network diversity (HNd). Samples labelled Stegastes beebei do not include samples collected at Guadalupe Island, which are here assigned to the species S. leucorus.

\begin{tabular}{lcccccccc}
\hline Species & $n$ & Seq. & pol. & $\mathrm{nH}$ & $\pi$ & $\mathrm{Hd}$ & $\mathrm{Nd}$ & $\mathrm{HNd}$ \\
\hline Endemic & & & & & & & & \\
$\quad$ Dialommus fuscus & 48 & 338 & 39 & 37 & 0.022 & 0.928 & 0.821 & 0.761 \\
$\quad$ Lepidonectes corallicola & 40 & 298 & 57 & 38 & 0.025 & 0.997 & 0.871 & 0.869 \\
$\quad$ Lythrypnus gilberti & 36 & 599 & 28 & 22 & 0.072 & 0.849 & 0.622 & 0.528 \\
$\quad$ Malacoctenus zonogaster & 44 & 409 & 70 & 43 & 0.049 & 0.998 & 0.900 & 0.898 \\
Insular & & & & & & & & \\
$\quad$ Stegastes arcifrons & 39 & 388 & 22 & 27 & 0.008 & 0.947 & 0.809 & 0.766 \\
$\quad$ Stegastes beebei & 37 & 376 & 24 & 16 & 0.023 & 0.831 & 0.442 & 0.367 \\
$\begin{array}{l}\text { Panamic } \\
\quad \text { Abudefduf troschelii }\end{array}$ & 67 & 539 & 105 & 63 & 0.032 & 0.997 & 0.925 & 0.922 \\
$\quad$ Holacanthus passer & 40 & 522 & 62 & 31 & 0.026 & 0.977 & 0.782 & 0.764 \\
\hline
\end{tabular}

could not find a direct relationship between habitat type (intertidal/subtidal) and population structure. However, D. fuscus, which is found in the highest intertidal areas, did show the highest levels of $F_{\mathrm{ST}}$.

\section{Inference of Population History}

Relative population sizes (estimates of theta, $\Theta$ ) and population growth are provided in Table 4. No clear trend was observed between the three groups of fishes. The two Stegastes species and the endemic goby, Lythrypnus showed high values of growth (898.9, 925.2, and 2308.2, respectively), suggesting a recent population expansion. Coalescence times were used to estimate the relative age of the populations (Crandall et al. 2012). Here again there was no clear trend that would separate the different groups of species, yet a high value singled out the high intertidal endemic D. fuscus $(533,000$ to 603,000 yrs).

\section{Discussion}

The impetus of this work was to test predictions of population structure in endemic, insular, and Panamic species of fish in the tropical eastern Pacific and the Galápagos Archipelago. We predicted that endemic species would exhibit low levels of population size, genetic diversity, and dispersal, and strong population structure. In contrast, widespread species would show high genetic diversity, large population size and high dispersal, resulting in weak population structure. Insular species have an intermediate type of distribution, being present both in the Galapagos Archipelago and the adjacent islands. Thus, we predicted an intermediate genetic pattern. We also wanted to determine if key life history traits may alter or confound these results. Besides the case of a strong signature of population structure in $D$. fuscus, which is a species that lives in the highest intertidal zone and spends a significant amount of time out of the water, we did not find obvious relationships between population structure and life history traits. 
Table 4. Demographic parameters of Galápagos fishes based on mtDNA control region. Number of sampled locales (populations, $n$ ), average $\Phi_{\mathrm{ST}}$ and number of statistically significant pairwise $\Phi_{\mathrm{ST}}$ values are provided in the first three columns. Only locales with more than 3 individuals were used. Estimates of theta $(\theta$; compound parameter representing the effective population size and mutation rate) when growth is constant, and variable are given in the next two columns, $g$ (growth parameter), and coalescence time (in thousands of years) based on mitochondrial control region data and in the last two columns. The standard deviation is presented between parentheses after each estimator when applicable.

\begin{tabular}{|c|c|c|c|c|c|c|c|}
\hline Species & $n$ & $\begin{array}{c}\text { Average } \\
\Phi_{\mathrm{ST}}\end{array}$ & $\begin{array}{c}\text { Significant } \\
\Phi_{\text {ST }} \\
\end{array}$ & $\theta \mathrm{c}(\mathrm{SD})$ & $\theta \mathrm{v}(\mathrm{SD})$ & $\mathrm{g}(\mathrm{SD})$ & $\begin{array}{l}\text { Coalescence } \\
\text { time (in ky) }\end{array}$ \\
\hline \multicolumn{8}{|l|}{ Endemic } \\
\hline Dialommus fuscus & 3 & 0.173 & 3 & $0.079(0.004)$ & $0.125(0.020)$ & $92.8(19.7)$ & $533.6-602.2$ \\
\hline Lepidonectes corallicola & 5 & 0.036 & 4 & $0.245(0.014)$ & $6.899(5.075)$ & $379.2(62.0)$ & $130.6-147.3$ \\
\hline Lythrypnus gilberti & 5 & 0.000 & 2 & $0.019(0.002)$ & $0.254(0.096)$ & $2,308.2(184.1)$ & $21.4-24.2$ \\
\hline Malacoctenus zonogaster & 5 & 0.000 & 0 & $0.289(0.023)$ & $2.289(0.462)$ & $255.2(45.4)$ & 194.0-218.9 \\
\hline \multicolumn{8}{|l|}{ Insular } \\
\hline Stegastes arcifrons & 5 & 0.011 & 0 & $0.037(0.002)$ & $0.346(0.096)$ & $898.9(188.7)$ & $55.1-62.2$ \\
\hline Stegastes beebei & 6 & 0.006 & 0 & $0.023(0.001)$ & $0.171(0.138)$ & $925.2(376.9)$ & $53.5-60.4$ \\
\hline \multicolumn{8}{|l|}{ Panamic } \\
\hline Abudefduf troschelii & 5 & 0.018 & 3 & $0.206(0.007)$ & $0.520(0.063)$ & $172.4(19.5)$ & $287.2-324.2$ \\
\hline Holacanthus passer & 7 & 0.000 & 0 & $0.057(0.002)$ & $0.080(0.004)$ & $103.8(6.9)$ & $477.0-538.4$ \\
\hline
\end{tabular}

As a word of caution, this study had a number of potential biases. There was a taxonomic bias, because all endemic species were blennioids or gobies, which are potentially more prone to population structure (Riginos and Victor 2001), as opposed to the remaining species that were predominantly damselfishes. Another potential bias was that our study was based on limited sample sizes and on a single molecular marker. Due to its remoteness and protected status, the Galápagos Archipelago is still a place where sampling remains complicated and logistic issues prevented us from further sampling. We hope that the results highlighted in this study will be used as a starting point for additional investigations. The use of a single mitochondrial marker is often criticized (Rubinoff et al. 2006); however, recent studies have shown that their use provide unique insights that are not always improved by the use of multiple loci (Drew and Barber 2012, Karl et al. 2012). In particular, the mitochondrial control region has been shown to have mutation rates that provide resolution across the spatial and temporal scales that are described in our study (Bernardi et al. 2003, Bernardi and Lape 2005, Drew and Barber 2012).

\section{Population Structure at Large Geographic Scales}

Population structure was found to be weak in insular and Panamic species, indicating substantial levels of connectivity between populations. A number of factors are implicated in explaining these results, including the dispersal capability of the target species, and the current regimes of the region. In addition, while the heterogeneity of shallow habitats seem propitious to physical separation, thus creating allopatric populations (Hastings 2000), the recent discovery of deep reefs and their associated kelp forests (Graham et al. 2007, Santelices 2007), may represent a more uniform deeper habitat that allow species to migrate within the region using these reefs as stepping stones (Poortvliet et al. 2013). 


\section{Population Structure and Endemism}

The comparative method used in the present study sheds light on some specific predictions that correlate endemism and genetic signatures. We did not find a clear gradient of population size and population structure when using Panamic, insular, and Galápagos endemic reef fish species, however, some important patterns emerged from our study. The highest number of statistically significant population pairwise $F_{\mathrm{ST}}$ comparisons was found in endemic species. In addition, coalescent approaches show that the demographic history is complex and displays high variability among different species. These results are the likely consequences of the high variability of the marine environment of the Galápagos Archipelago. In the Galápagos, major oceanographic zones have been identified, dividing the Archipelago into 5 ecological zones, with tropical regions in the north, and areas subjected to seasonal upwellings in the west (Glynn and Wellington 1983). Yet, significant temperature changes within these zones do occur both seasonally (summer and winter seasons) and at larger scales (El Nino-La Nina Southern Oscillatory events, ENSOs), influencing the local distribution of fishes (Grove 1984, McCosker 1987). These changes, in turn, are a likely source of vast contractions and expansions of fish populations, as exemplified in an extreme example by the extinction of the endemic Galápagos damsel, Azurina eupalama Heller and Snodgrass 1903, which apparently disappeared after the 19821983 ENSO event (Grove and Lavenberg 1997, McCosker and Rosenblatt 2010).

\section{Population Structure Within the Galápagos Archipelago}

Endemic species have traditionally been seen as poor dispersers, being "stuck" on oceanic islands after a rare chance event that allowed them to colonize such distant islands (Eble et al. 2009). The poor dispersal ability is predicted to also result in low levels of population structure, and this is indeed what we observe with our data. Three out of four endemic species show significant population pairwise $F_{\mathrm{ST}}$, and the Galápagos four-eyed blenny, D. fuscus, which lives in the uppermost intertidal areas, shows the highest values of $F_{\mathrm{ST}}$. The Galápagos Islands are famous for harboring distinct populations of giant tortoises, mockingbirds, finches, and land and marine iguanas on different islands. While the results presented here do not yet show such striking patterns, the southern islands of Española and Floreana and the remaining islands showed evidence of population structure in three endemic species. Additional samples and molecular markers will be needed to determine if this pattern holds.

\section{ACKNOWLEDGMENTS}

We would like to thank the Galápagos National Park for permission to collect samples under permit PC-30-99-PNG and the Charles Darwin Research Station for logistical support. We would also like to thank B Ruttenberg, JB Heiser, M Cardenas, and G and G Bernardi for help in the field, and G Garrison for discussions on the distribution of fishes at Cocos Island. We would like to thank C Riginos for providing comments on the manuscript. D Pauly graciously accepted to share the title of his excellent book with us, and engage in valuable discussions on Darwin and the Galápagos Islands. This research was funded by the University of California Santa Cruz. This publication is contribution number 2088 of the Charles Darwin Foundation for the Galápagos Islands. 


\section{Literature Cited}

Allen GR, Robertson DR. 1994. Fishes of the tropical eastern Pacific. Honolulu, Hawaii: University of Hawaii Press.

Allen GR, Woods LP. 1980. A review of the damselfish genus Stegastes from the eastern Pacific with the description of a new species. Records of the Western Australian Museum 8: 171-198.

Allen GR. 1991. Damselfishes of the World. Mentor, Ohio: Aquarium Systems.

Alva-Campbell Y, Floeter SR, Robertson DR, Bellwood DR, Bernardi G. 2010. Molecular phylogenetics and evolution of Holacanthus angelfishes (Pomacanthidae). Mol Phylogenet Evol. 56:456-61. PMid:20171293. http://dx.doi.org/10.1016/j.ympev.2010.02.014

Avise JC. 1992. Molecular population structure and the biogeographic history of a regional fauna: a case history with lessons for conservation biology. Oikos. 63:62-76. http://dx.doi. org/10.2307/3545516

Avise JC. 2000. Phylogeography: the history and formation of species. Cambridge, MA: Harvard University Press.

Baldwin BG, Sanderson MJ. 1998. Age and rate of diversification of the Hawaiian silversword alliance (Compositae). Proc Natl Acad Sci USA. 95:9402-9406. PMid:9689092. http:// dx.doi.org/10.1073/pnas.95.16.9402

Barluenga M, Stölting KN, Salzburger W, Muschick M, Meyer A. 2006. Sympatric speciation in Nicaraguan crater lake cichlid fish. Nature. 439:719-23. PMid:16467837. http://dx.doi. org/10.1038/nature04325

Bernardi G, Findley L, Rocha-Olivares A. 2003. Vicariance and dispersal across Baja California in disjunct marine fish populations. Evolution. 57:1599-1609. PMid:12940364.

Bernardi G, Lape J. 2005. Tempo and mode of speciation in the Baja California disjunct fish species Anisotremus davidsonii. Mol Ecol. 14:4085-4096. PMid:16262860. http://dx.doi. org/10.1111/j.1365-294X.2005.02729.X

Bernardi G. 2013. Speciation in fishes. Mol Ecol. 22:5487-5502. PMid:24118417. http://dx.doi. org/10.1111/mec.12494

Berumen ML, Almany GR, Planes S, Jones GP, Saenz-Agudelo P, Thorrold SR. 2012. Persistence of self-recruitment and patterns of larval connectivity in a marine protected area network. Ecol Evol. 2:444-452. PMid:22423335. PMCid:PMC3298954. http://dx.doi.org/10.1002/ ece3.208

Briggs JC, Bowen BW. 2012. A realignment of marine biogeographic provinces with particular reference to fish distributions. J Biogeogr. 39:12-30. http://dx.doi. org/10.1111/j.1365-2699.2011.02613.x

Bussing WA, Lopez MI. 2005. Fishes of Cocos Island and reef fishes of the Pacific coast of lower Central America. Revista de Biologia Tropical. 53:S1-S192.

Clark HW. 1936. New and noteworthy fishes. The Templeton Crocker expedition of the California Academy of Sciences, 1932. Proc California Acad Sci. 21:383-396.

Coyne JA, Orr HA. 2004. Speciation. Sunderland, MA.: Sinauer Associates Inc.

Crandall ED, Sbrocco EJ, Deboer TS, Barber PH, Carpenter KE. 2012. Expansion dating: calibrating molecular clocks in marine species from expansions onto the Sunda Shelf Following the Last Glacial Maximum. Mol Biol Evol. 29:707-719. PMid:21926069. http://dx.doi. org $/ 10.1093 / \mathrm{molbev} / \mathrm{msr} 227$

Crow KD, Munehara H, Bernardi G. 2010. Sympatric speciation in a genus of marine reef fishes. Mol Ecol. 19:2089-105. PMid:20345669. http://dx.doi. org/10.1111/j.1365-294X.2010.04611.X

Darwin C. 1845. Journal of researches into the natural history and geology of the countries visited during the voyage of H.M.S. BEAGLE round the world. London.

Darwin C. 1859. On the origin of species by means of natural selection, or the preservation of favoured races in the struggle for life. John Murray. 
Doherty PJ, Planes S, Mather P. 1995. Gene flow and larval duration in seven species of fish from the Great Barrier Reef. Ecology. 76:2373-2391. http://dx.doi.org/10.2307/2265814

Domingues VS, Bucciarelli G, Almada VC, Bernardi G. 2005. Historical colonization and demography of the Mediterranean damselfish, Chromis chromis. Mol Ecol. 14:4051-4063. PMid:16262858. http://dx.doi.org/10.1111/j.1365-294X.2005.02723.x

Domingues VS, Santos RS, Brito A, Almada VC. 2006. Historical population dynamics and demography of the eastern Atlantic pomacentrid Chromis limbata (Valenciennes, 1833). Mol Phylogenet Evol. 40:139-147. PMid:16603388. http://dx.doi.org/10.1016/j. ympev.2006.02.009

Drew JA, Barber PH. 2012. Comparative phylogeography in Fijian coral reef fishes: a multitaxa approach towards marine reserve design. PLoS ONE. 7:e47710. PMid:23118892. PMCid:PMC3484158. http://dx.doi.org/10.1371/journal.pone.0047710

Duda TF, Rolán E. 2005. Explosive radiation of Cape Verde Conus, a marine species flock. Mol Ecol. 14:267-72. PMid:15643969. http://dx.doi.org/10.1111/j.1365-294X.2004.02397.x-

Eble JA, Toonen RT, Bowen BW. 2009. Endemism and dispersal: comparative phylogeography of three surgeonfishes across the Hawaiian Archipelago. Mar Biol. 156:689-698. http:// dx.doi.org/10.1007/s00227-008-1119-4

Excoffier L, Lischer HEL. 2010. Arlequin suite ver 3.5: a new series of programs to perform population genetics analyses under Linux and Windows. Mol Ecol Res. 10:564-567. PMid:21565059. http://dx.doi.org/10.1111/j.1755-0998.2010.02847.x

Excoffier L, Smouse PE, Quattro JM. 1992. Analysis of molecular variance inferred from metric distances among DNA haplotypes: application to human mitochondrial DNA restriction data. Genetics. 131:479-491. PMid:1644282.

Excoffier L, Smouse PE. 1994. Using allele frequencies and geographic subdivision to reconstruct gene trees within a species: molecular variance parsimony. Genetics. 136:343-59. PMid:8138170.

Garrison G. 2005. Peces de la Isla del Coco / Isla del Coco Fishes. Santo Domingo de Heredia. Costa Rica.: Instituto Nacional de Biodiversidad.

Glynn PW, Wellington GM. 1983. Corals and coral reefs of the Galapagos islands. Berkeley: University of California Press.

Graham MH, Kinlan BP, Druehl LD, Garske LE, Banks S. 2007. Deep-water kelp refugia as potential hotspots of tropical marine diversity and productivity. Proc Natl Acad Sci USA. 104:16,576-16,580. PMid:17913882. PMCid:PMC2034254. http://dx.doi.org/10.1073/ pnas.0704778104

Grant PR. 2000. Ecology and evolution of Darwin's finches. Princeton, New Jersey: Princeton University Press.

Gravilets S. 2004. Fitness landscapes and the origin of species. Princeton, New Jersey: Princeton University Press.

Grove JS, Lavenberg RJ. 1997. The fishes of the Galápagos Islands. Stanford University Press.

Grove JS. 1984. Influence of the 1982-1983 El-Niño on the ichthyofauna on the Galápagos archipelago. Trop Ocean-Atmos. Newsletter 28.

Hastings P. 2000. Biogeography of the tropical eastern Pacific: distribution and phylogeny of chaenopsid fishes. Zool J Linnean Soc. 128:319-335. http://dx.doi. org/10.1111/j.1096-3642.2000.tbo0166.X

Herald ES, Herald OW. 1973. The Galapagos four-eyed blenny. Pac Discovery. 26:28-30.

Herder F, Nolte AW, Pfaender J, Schwarzer J, Hadiaty RK, Schliewen UK. 2006. Adaptive radiation and hybridization in Wallace's Dreamponds: evidence from sailfin silversides in the Malili Lakes of Sulawesi. Proc R Soc B Biol Sci, London. 273:2209-2217. PMid:16901841. PMCid:PMC1635519.

Huang D, Bernardi G. 2001. Disjunct Sea of Cortez-Pacific Ocean Gillichthys mirabilis populations and the evolutionary origin of their Sea of Cortez endemic relative, Gillichthys seta. Mar Biol. 138:421-428. http://dx.doi.org/10.1007/s002270000454 
Humann P, DeLoach N. 2003. Reef fish identification, Galápagos. Jacksonville, FL: New World Publications. PMid:12972655. PMCid:PMC281594.

Jackson M. 1985. Galapagos. A natural history guide. Calgary, Alberta, Canada: The University of Calgary Press.

Jones GP, Milicich MJ, Emslie MJ, Lunow C. 1999. Self-recruitment in a coral reef fish population. Nature. 402:802-804. http://dx.doi.org/10.1038/45538

Jones GI, PTanes S, Thorrold SR. 2005. Coral reef fish larvae settle close to home. Curr Biol. 15: 1314-1318. PMid:16051176. http://dx.dol.org/10.1016/J.cub.2005.06.061

Kahindo C, Bowie R, Bates J. 2007. The relevance of data on genetic diversity for the conservation of Afro-montane regions. Biol Conserv. 134:262-270. http://dx.doi.org/10.1016/j. biocon.2006.08.019

Karl S a, Toonen RJ, Grant WS, Bowen BW. 2012. Common misconceptions in molecular ecology: echoes of the modern synthesis. Mol Ecol. 21:4171-4189. PMid:22574714. http:// dx.doi.org/10.1111/j.1365-294X.2012.05576.X

Katoh K, Misawa K, Kuma K, Miyata T. 2002. MAFFT: a novel method for rapid multiple sequence alignment basedon fast Fourier transform. Nucleic Acids Res. 30:3059-3066. PMid:12136088. PMCid:PMC135756. http://dx.doi.org/10.1093/nar/gkt436

Kelly RP, Palumbi SR. 2010. Genetic structure among 50 species of the northeastern Pacific rocky intertidal community. PloS ONE. 5:e8594. PMid:20062807. PMCid:PMC2799524. http://dx.doi.org/10.1371/journal.pone.0008594

Klanten SO, Herwerden Lv L Van, Choat )H, Blair D. 2004. Patterns of lineage diversification in the genus Naso (Acanthuridae). Mol Phylogenet Evol. 32:221-235. PMid:15186809. http:// dx.doi.org/10.1016/j.ympev.2003.11.008

Kuhner MK. 2006. LAMARC 2.0: maximum likelihood and Bayesian estimation of population parameters. Bioinformatics. 22:768-770. PMid:16410317. http://dx.doi.org/10.1093/ bioinformatics/btk051

Lack D. 1947. Darwin's finches. Cambridge: Cambridge University Press. PMid:20264594.

Larson EJ. 2001. Evolution's Workshop: god and science on the Galapagos Islands. New York: Basic Books and London: Penguin.

Lee WJ, Conroy J, Howell WH, Kocher TD. 1995. Structure and evolution of teleost mitochondrial control regions. J Mol Evol. 41:54-66. PMid:7608989. http://dx.doi.org/10.1007/ BF00174041

Leis JM. 1991. The pelagic stage of reef fishes. In: Sale P, editor. The ecology of fishes on coral reefs San Diego, CA: Academic Press, Inc. p. 182-229. http://dx.doi.org/10.1016/ B978-0-08-092551-6.50013-1

Librado P, Rozas J. 2009. DnaSP v5: a software for comprehensive analysis of DNA polymorphism data. Bioinformatics. 25:1451-1452. PMid:19346325. http://dx.doi.org/10.1093/ bioinformatics/btpI87

Luiz OJ, Allen AP, Robertson DR, Floeter SR, Kulbicki M, Vigliola L, Becheler R, Madin JS. 2013. Adult and larval traits as determinants of geographic range size among tropical reef fishes. Proc Natl Acad Sci USA. 41:16,498-16,502. PMid:24065830. PMCid:PMC3799316. http://dx.doi.org/10.1073/pnas.1304074110

McCosker JE, Rosenblatt RH. 1975. Fishes collected at Malpelo Island. In: Graham J, editor. The biological investigation of Malpelo Island, Colombia Smithsonian Contributions Zoology.

McCosker JE, Rosenblatt RH. 1984. The inshore fish fauna of the Galápagos Islands. In: Perry R, editor. Key Environments-Galápagos Pergamon Press. p. 133-144.

McCosker JE, Rosenblatt RH. 2010. The fishes of the Galápagos Archipelago: an update. Proc California Acad Sci. 61:167-195.

McCosker JE, Stephens JS, Rosenblatt RH. 2003. Cottoclinus canops, a new genus and species of blenny (Perciformes : Labrisomidae) from the Galápagos Islands. Proc California Acad Sci. 54:155-160.

McCosker JE. 1987. The fishes of the Galápagos Islands. Oceanus. 30:28-32. 
Miglietta MP, Faucci A, Santini F. 2011. Speciation in the sea: overview of the symposium and discussion of future directions. Integr Comp Biol. 51:449-455. PMid:21593140. http:// dx.doi.org/10.1093/icb/icr024

Muss A, Robertson DR, Stepien CA, Wirtz P, Bowen BW. 2001. Phylogeography of Ophioblennius: the role of ocean currents and geography in reef fish evolution. Evolution. 55:561-572. http://dx.doi.org/10.1554/0014-3820(2001)055[0561:POOTRO]2.0.CO;2

Nei M. 1987. Molecular evolutionary genetics. New York: Columbia University Press.

Nieder J. 2001. Amphibious behaviour and feeding ecology of the four-eyed blenny (Dialommus fuscus, Labrisomidae) in the intertidal zone of the island of Santa Cruz (Galapagos, Ecuador). J Fish Biol. 58:755-767. http://dx.doi.org/10.1111/j.1095-8649.2001.tb00528.x

Palumbi SR. 1994. Genetic divergence, reproductive isolation and marine speciation. Ann Rev Ecol Syst. 25:547-572. http://dx.doi.org/10.1146/annurev.es.25.110194.002555

Paradis E, Claude J, Strimmer K. 2004. APE: analyses of phylogenetics and evolution in R language. Bioinformatics. 20:289-290. PMid:14734327. http://dx.doi.org/10.1093/ bioinformatics/btg412

Planes AS, Fauvelot C. 2002. Isolation by distance and vicariance drive genetic structure of a coral reef fish in the Pacific Ocean. Evolution. 56:378-399. PMid:11926506.

Poortvliet M, Longo GC, Selkoe K, Barber PH, Crow W, Caselle JE, Perez-Matus A, Gaines SD, Bernardi G. 2013. Phylogeography of the California sheephead, Semicossyphus pulcher: the role of deep reefs as stepping stones and pathways to antitropicality. Ecol Evol. 3:45584571. PMid:24340195. PMCid:PMC3856754. http://dx.doi.org/10.1002/ece3.840

Posada D, Crandall KA. 1998. MODELTEST: testing the model of DNA substitution. Bioinformatics. 14:817-818. PMid:9918953. http://dx.doi.org/10.1093/ bioinformatics/14.9.817

Price T. 2007. Speciation in birds. Greenwood Village, Colorado: Roberts \& Company Publishers.

Priest MA, Halford AR, McIlwain JL. 2012. Evidence of stable genetic structure across a remote island archipelago through self-recruitment in a widely dispersed coral reef fish. Ecol Evol. 2:3195-213. PMid:23301184. PMCid:PMC3539012. http://dx.doi.org/10.1002/ece3.260

Riginos C, Douglas KE, Jin Y, Shanahan DF, Treml E. 2011. Effects of geography and life history traits on genetic differentiation in benthic marine fishes. Ecography. 34:566-575. http:// dx.doi.org/10.1111/j.1600-0587.2010.06511.x

Riginos C, Victor BC. 2001. Larval spatial distributions and other early life-history characteristics predict genetic differentiation in eastern Pacific blennioid fishes. Proc R Soc B Biol Sci, London. 268:1931-1936. PMid:11564350. PMCid:PMC1088830.

Rocha LA, Bowen BW. 2008. Speciation in coral-reef fishes. J Fish Biol. 72:1101-1121. http:// dx.doi.org/10.1111/j.1095-8649.2007.01770.x

Roderick GK, Croucher PJP, Vandergast AG, Gillespie RG. 2012. Species differentiation on a dynamic landscape: shifts in metapopulation genetic structure using the chronology of the Hawaiian Archipelago. Evol Biol. 39:192-206. PMid:22707805. PMCid:PMC3364410. http://dx.doi.org/10.1007/s11692-012-9184-5

Rubinoff D, Cameron S, Will K. 2006. A genomic perspective on the shortcomings of mitochondrial DNA for "barcoding" identification. J Heredity. 97:581-594. PMid:17135463. http://dx.doi.org/10.1093/jhered/esl036

Santelices B. 2007. The discovery of kelp forests in deep-water habitats of tropical regions. Proc Natl Acad Sci USA. 104:19,163-19,164. PMid:18042707. PMCid:PMC2148260. http:// dx.doi.org/10.1073/pnas.0708963104

Savolainen V, Anstett M, Lexer C, Hutton I, Clarkson JJ, Norup MV, Powell MP, Springate D, Salamin N, Baker WJ. 2006. Sympatric speciation in palms on an oceanic island. Nature. 441:210-213. PMid:16467788. http://dx.doi.org/10.1038/nature04566

Selkoe K, Toonen R. 2011. Marine connectivity: a new look at pelagic larval duration and genetic metrics of dispersal. Mar Ecol Prog Ser. 436:291-305. http://dx.doi.org/10.3354/ meps09238 
Selkoe KA, Watson JR, White C, Horin T, Toonen RJ. 2010. Taking the chaos out of genetic patchiness: seascape genetics reveals ecological and oceanographic drivers of genetic patterns in three temperate reef species. Mol Ecol. 19:3708-3726. PMid:20723063. http:// dx.doi.org/10.1111/j.1365-294X.2010.04658.x

Shulman MJ, Bermingham E. 1995. Early life histories, ocean currents, and the population-genetics of Caribbean reef fishes. Evolution. 49:897-910. http://dx.doi.org/10.2307/2410412

Stepien CA, Dixon MT, Hillis DM. 1993. Evolutionary relationships of the blennioid fish families Clinidae, Labrisomidae, and Chaenopsidae: congruence between DNA sequence and allozyme data. Bull Mar Sci. 52:496-515.

Swearer SE, Caselle JE, Lea DW, Warner RT. 1999. Larval retention and recruitment in an island population of a coral-reef fish. Nature. 402:799-802. http://dx.doi.org/10.1038/45533

Thorpe RS. 2005. Population evolution and island biogeography. Science. 310:1778-1779. PMid:16357251. http://dx.doi.org/10.1126/science.1122457

Treml EA, Roberts J, Chao Y, Halpin PN, Possingham HP, Riginos C. 2012. Reproductive output and duration of the pelagic larval stage determine seascape-wide connectivity of marine populations. Integr Comp Biol. 52:525-537. PMid:22821585. http://dx.doi.org/10.1093/ $\mathrm{icb} / \mathrm{ics} 101$

van der Meer MH, Hobbs J-P, Jones GP, van Herwerden L. 2012. Genetic connectivity among and self-replenishment within island populations of a restricted range subtropical reef fish. PloS ONE. 7:e49660. PMid:23185398. PMCid:PMC3504158. http://dx.doi.org/10.1371/ journal.pone.0049660

von der Heyden S, Gildenhuys E, Bernardi G, Bowie RCK. 2013. Fine scale biogeography: tidal elevation strongly affects population genetic structure and demographic history in intertidal fishes. Front Biogeogr. 5:29-38.

Waples RS. 1987. A multispecies approach to the analysis of gene flow in marine shore fishes. Evolution. 41:385-400. http://dx.doi.org/10.2307/2409146

Wares TP, Cunningham CW. 2001. Phylogeography and historical ecology of the North Atlantic intertidal. Evolution. 55: 2455-2469. PMid:11831661.

Wellington GM, Victor BC. 1989. PTanktonic larval duration of one hundred species of Pacific and Atlantic damselfishes (Pomacentridae). Mar Biol. 101:557-567. http://dx.doi. org/10.1007/BF00541659

Winters KL, Herwerden L, Choat JH, Robertson DR. 2010. Phylogeography of the Indo-Pacific parrotfish Scarus psittacus: isolation generates distinctive peripheral populations in two oceans. Mar Biol. 157:1679-1691. http://dx.doi.org/10.1007/s00227-010-1442-4

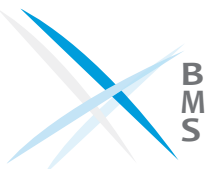

